\title{
Changes in macrophyte communities in Lake Swarzędzkie after the first year of restoration
}

\author{
Joanna Rosińska, Ryszard Gołdyn
}

Received - 06 October 2014/Accepted - 22 January 2015. Published online: 31 March 2015; @Inland Fisheries Institute in Olsztyn, Poland Citation: Rosińska J., Gołdyn R. 2015 - Changes in macrophyte communities in Lake Swarzędzkie after the first year of restoration - Arch. Pol. Fish. 23: 43-52.

\begin{abstract}
Lake Swarzędzkie, near Poznań, was a hypertrophic lake because of its high nutrient content, cyanobacteria blooms, and disruptive recreational use, especially swimming, which was popular there. This is why protection measures have been in place since 1991, and a restoration program has been ongoing since fall 2011. The evaluation of the presence and distribution of macrophytes as an important element of lake ecosystem was conducted in August 2012. Nine plant communities were observed: Phragmitetum communis; Typhetum angustifoliae; Nupharo-Nymphaeetum albae; Hydrocharitetum morsus-ranae; Thelypteridi-Phragmitetum; Cicuto-Caricetum pseudocyperi; Acoretum calami; Ceratophylletum demersi; Potametum lucentis. The first three were dominating associations. The presence of submerged vegetation appears to verify the positive impact of the applied conservation and restoration measures. Improvement is confirmed by the significant decrease in concentrations of chlorophyll-a and total nitrogen, as well as the gradual decrease in total suspended solids and increased transparency.
\end{abstract}

Keywords: lake restoration, macrophyte response, chlorophyll-a, transparency

J. Rosińska [ "’], R. Gołdyn

Department of Water Protection

Faculty of Biology, Adam Mickiewicz University

Umultowska 89, 61-614 Poznań, Poland

e-mai: rosinska.asia@gmail.com

\section{Introduction}

According to the European Water Framework Directive, by 2015 the water in Polish lakes should have achieved good status. Assessments of ecological status are determined mainly by biological indicators such as phytoplankton, macrophytes, phytobenthos, macrozoobenthos, and fish (Ciecierska and Kolada 2014). Developing appropriate approaches to water and sewage management in catchment areas and eliminating sources of pollution are essential to obtaining good status. If an aquatic ecosystem is unable to restore itself to good condition, restoration treatments should be used to improve water quality. Processes that occur in lakes are complex, and, despite research, they are not fully understood, which is why conducting successful restoration leading to long-term improvements in water quality in water bodies is difficult (Pieczyńska 1993, Gołdyn et al. 2014).

Aquatic vegetation is a very good bioindicator of the trophic status of water bodies as it is indicative of long-term changes. Transformations in the composition of aquatic vegetation are often delayed compared to those of phyto- and zooplankton, which respond quickly to disturbances because of sudden decreases in nutrient supply. Submerged macrophytes are very sensitive to changes in habitat conditions (Kolada 2010, Kłosowski et al. 2011). They provide important information about changes and

\footnotetext{
C Copyright by Stanisław Sakowicz Inland Fisheries Institute in Olsztyn.

(C) 2015 Author(s). This is an open access article licensed under the Creative Commons Attribution-NonCommercial-NoDerivs License (http://creativecommons.org/licenses/by-nc-nd/3.0/).
} 
developmental stages in lakes (Nagengast 1994, Melzer 1999, Søndergaard et al. 2010). The distribution and abundance of aquatic plants illustrate biological, chemical, and physical parameters in water ecosystems (Ciecierska and Kolada 2014). Their presence depends on light availability, among other factors, and they disappear when nutrient concentrations increase, because this stimulates strong phytoplankton growth that decreases transparency. Helophytes, however, are sensitive to changes in littoral zone water levels. Therefore, determining macrophyte condition is an important element of ecological assessments of aquatic ecosystems (Kolada 2014).

Macrophytes play a key role in the functioning and maintenance of ecological balance in shallow lakes. They form a buffer zone, with an intense turnover of matter, that actively stores nutrients from sediments and the water (Ozimek et al. 1990, Ciurli et al. 2009, Wang et al. 2009). They increase water transparency (Wang et al. 2009), oxygenate the water column (Ciurli et al. 2009), prevent the resuspension of sediments, and stabilize the bottom (Kolada and Ciecierska 2008, Ciurli et al. 2009, Kuczyńska-Kippen 2009). Nutrient uptake from the water is enhanced by macrophytes, periphyton, and microorganisms (Srivastava et al. 2008), which contributes to maintaining clear water in lakes (Hao et al. 2013; Immersa et al. 2014).

Submerged macrophytes play significant roles in trophic chains in shallow lakes (Mulderij et al. 2007). First, they provide a food base (Liu et al. 2014) and habitats, spawning grounds, and refuge for many aquatic organisms such as zooplankton (Kuczyńska-Kippen et al. 2009, Liu et al. 2014), macrozoobenthos, fish, and waterfowl (Ciurli et al. 2009), which increases biodiversity in lakes (Mulderij et al. 2007). Appropriate submerged macrophyte coverage leads to increased numbers of predatory fish (Schriver et al. 1995). The presence of Nuphar lutea (L.) Sm. also has a positive effect on predators as it provides refuge, especially for pike, Esox lucius L. (Ozimek et al. 1990).

Hydromacrophytes limit the growth of phytoplankton (Wang et al. 2009) by competing with them for nutrients and light (Ciurliě et al. 2009), and they also release allelopathic substances that inhibit the growth of phytoplankton. Many submerged macrophytes (e.g., Ceratophyllum demersum L.) can inhibit the growth of phytoplankton and contribute to changes in domination structure (eliminating cyanobacteria) (van Donk and van de Bund 2002, Mulderij et al. 2007, Celewicz-Gołdyn 2010).

These macrophyte roles mean that they are highly significant in lake restoration. The progressive spread of submerged macrophytes supports the transition from a stable turbid state with the dominance of phytoplankton into an alternative clear water stable state (Scheffer et al. 1993, Meijer 2000). They stabilize the ecosystem after water quality has been improved, and they sustain the long-term impacts of restoration measures (Hilt et al. 2006).

Lake Swarzędzkie is an example of a heavily eutrophic lake which is currently undergoing restoration. The aim of the study was to determine the impact restoration measures are having on macrophytes and changes in selected physicochemical water quality indicators during the first year these measures were implemented. The composition and distribution of aquatic vegetation communities was evaluated, and then these aspects were compared with data that had been collected prior to restoration. A detailed macrophyte map of this lake provides invaluable material for further comparative studies on changes in the composition and extent of the various communities during restoration.

\section{Material and methods}

The field research was conducted in August 2012. The macrophytes were mapped along the shoreline from a small boat. The presence, composition, and extent of occurrence of submerged macrophytes, nymphaeids, and helophytes in the lake was inventoried in the field. The communities were classified according to Podbielkowski and Tomaszewicz (1996). The dominant species in the patch was used to identify the community. The occurrence of submerged plants was checked using an anchor. The beginning, 
Table 1

Morphometry of Lake Swarzędzkie (Szyper et al. 1994, Kowalczewska-Madura and Gołdyn 2006)

\begin{tabular}{ll}
\hline \hline Parameter & Value \\
\hline \hline Lake area (ha) & $93.7 \mathrm{ha}$ \\
Mean depth & $2.6 \mathrm{~m}$ \\
Maximum depth & $7.2 \mathrm{~m}$ \\
Lake balance type & flow \\
Catchment area (ha) & $17825.8 \mathrm{ha}$ \\
Catchment type & agricultural \\
Lake trophy & hypertrophy \\
\hline \hline
\end{tabular}

end, and characteristic elements of every patch of macrophytes were noted with GPS. A visual map of the aquatic vegetation in Lake Swarzędzkie was prepared using ArcGIS.

After beginning restoration in October 2011, monthly monitoring was conducted in 2012 (12 field trips), during which physicochemical water quality variables were examined at the deepest place in the lake at depth profiles of every $1 \mathrm{~m}$ (Table 1 ). Water samples were taken using a $5 \mathrm{~L}$ bathometer. Dissolved oxygen and transparency (Secchi depth: SD) were measured in situ. Samples for total nitrogen and phosphorus analyses were preserved with chloroform and analyzed in the laboratory using standard methods (Elbanowska et al. 1999). Concentrations of chlorophyll-a and total suspended solids were assessed from unfixed samples (Table 2).

Statistical calculations were performed with STATISTICA v. 10. The data from two years of the study were compared using the U-test of the Mann-Whitney non-parametric statistics package.

\section{Results}

Nine plant communities were noted during the field research. The occurrence of emergent vegetation with floating leaves, pleustophytes, and submerged macrophytes was noted. The reed belt, $10-20 \mathrm{~m}$ in width, was well formed. Associations characteristic of eutrophic lakes dominated (Table 3) with the helophytes Phragmitetum communis and Typhetum angustifoliae and the nymphaeides Nupharo-Nymphaeetum albae. The latter occurred most frequently in the northeast near the inflow of the Cybina River into Lake Swarzędzkie, as well as in the shallow, southwestern part of the lake. Hydrocharitetum morsus-ranae, Thelypteridi-Phragmitetum, Cicuto-Caricetum pseudocyperi, and Acoretum calami were also present, as were two communities of submerged macrophytes - Ceratophylletum demersi covered by algal mats of Cladophora sp. and Potametum lucentis at one station (Fig. 1).

The physicochemical parameters of the water in the first year of restoration compared with data from 2011 (Kozak et al. 2014) indicated there had been notable changes, particularly in the surface layer (Table 2). Transparency (Secchi depth) was clearly higher than in 2011 and only in September was it less than $1.0 \mathrm{~m}$ (Fig. 2), although these changes were not statistically significant (Table 2). The concentration of

Table 2

Mean values $(n=12)$ of physicochemical parameters and standard deviation in the surface layer of Lake Swarzędzkie in 2011-2012

\begin{tabular}{llllll}
\hline \hline & & \multicolumn{2}{l}{ Mean \pm SD } & U-test \\
\cline { 3 - 6 } Parameter & Unit & 2011 & 2012 & $\mathrm{Z}$ & $\mathrm{P}$ \\
\hline \hline Dissolved oxygen & $\mathrm{mg} \mathrm{O}_{2} \mathrm{l}^{-1}$ & $12.9 \pm 3.2$ & $15.0 \pm 5.1$ & -0.926 & 0.355 \\
Seston & $\mathrm{mg} \mathrm{l}^{-1}$ & $16.2 \pm 10.5$ & $9.1 \pm 3.4$ & -1.621 & 0.105 \\
Chlorophyll-a & $\mu \mathrm{g} \mathrm{l}^{-1}$ & $83.0 \pm 59.6$ & $27.0 \pm 17.6$ & -2.392 & 0.017 \\
TN & $\mathrm{mg} \mathrm{N} \mathrm{I}^{-1}$ & $6.025 \pm 2.576$ & $2.486 \pm 1.171$ & -3.163 & 0.002 \\
TP & $\mathrm{mg} \mathrm{P} \mathrm{l}^{-1}$ & $0.132 \pm 0.060$ & $0.130 \pm 0.088$ & -0.616 & 0.537 \\
Secchi depth & $\mathrm{m}$ & $1.06 \pm 0.68$ & $1.34 \pm 0.44$ & -1.589 & 0.112 \\
\hline \hline
\end{tabular}




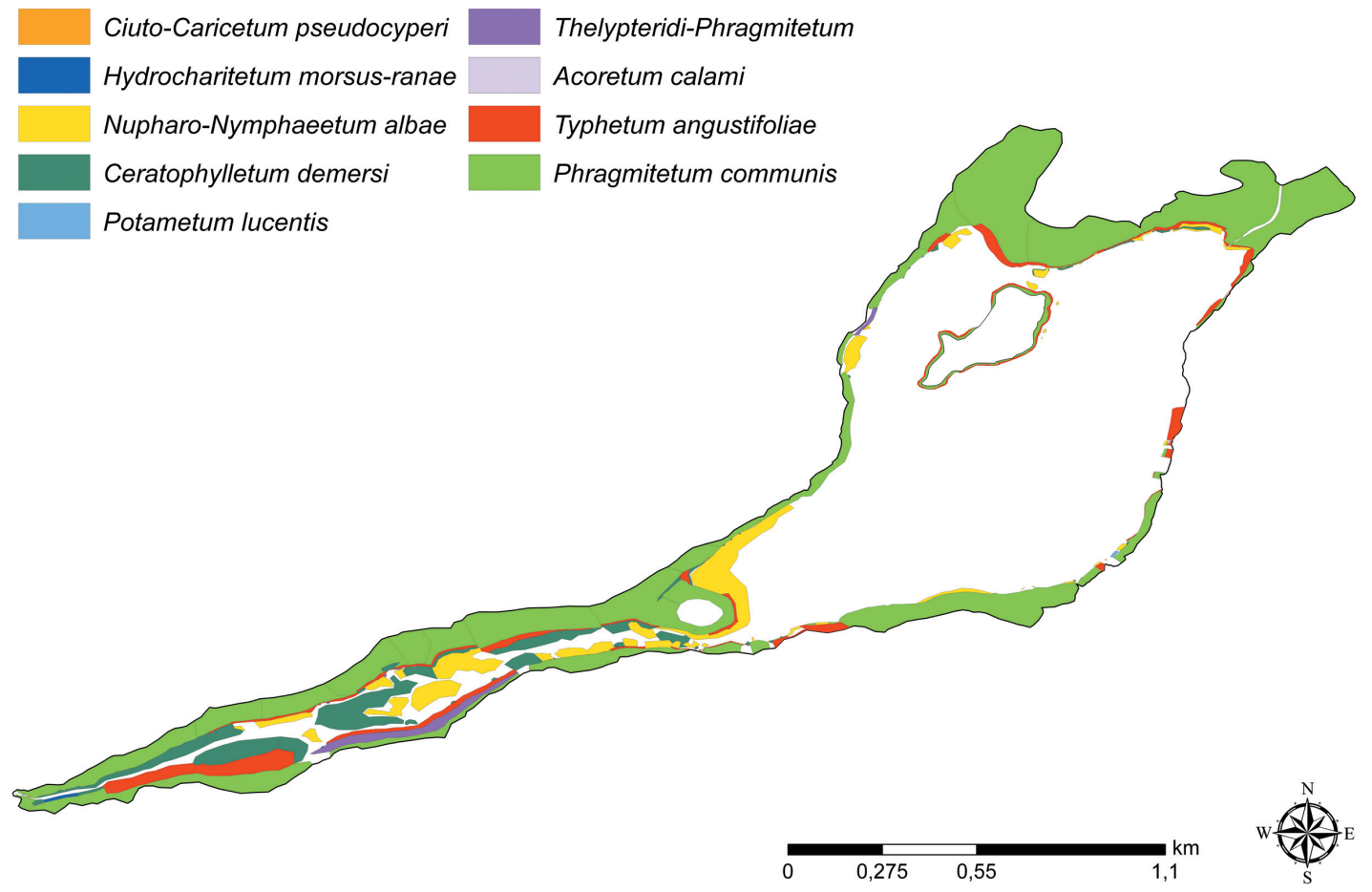

Figure 1. Map of the distribution of macrophyte communities in Lake Swarzędzkie in 2012.

chlorophyll-a was statistically significantly reduced, especially in the summer (Fig. 2). Moreover, the content of total suspended solids had decreased notably. Significantly lower concentrations of total nitrogen were observed. However, the values of total phosphorus had not changed (Table 2). Dynamics of transparency and chlorophyll-a concentration like those in Lake Swarzędzkie indicate there were changes in the concentration of nutrients in the water ecosystem (Oleksowicz 1988).

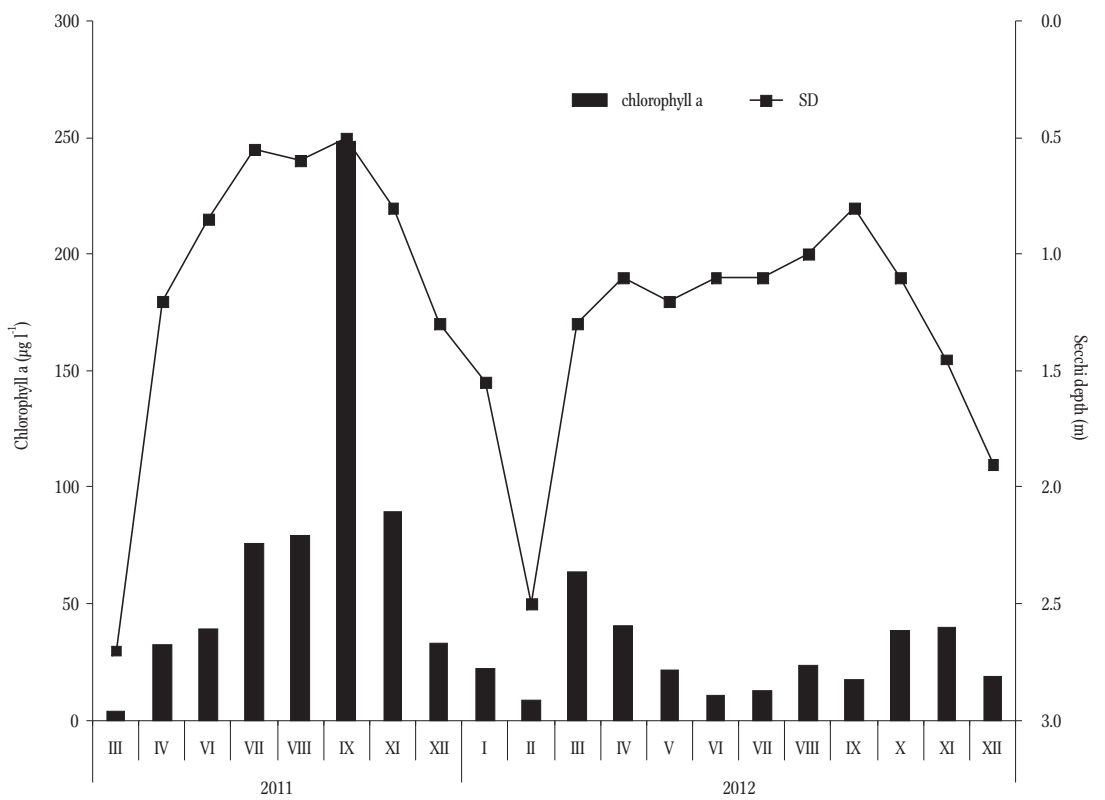

Figure 2. Transparency (SD) and concentrations of chlorophyll-a in the surface layer of Lake Swarzędzkie in 2011-2012.

\section{Discussion}

Upon analyzing data on the presence of macrophytes in Lake Swarzędzkie over 30 years (Table 3), the transformation of the lake's vegetation and the range

of occurrence of individual communities is apparent. According to Jenek et al. (1979), submerged vegetation occupied an area of approximately 28 hectares (about $30 \%$ of the total lake surface), while helophytes 
occupied 18 hectares (about $20 \%$ of the lake surface) 40 years ago. The complete disappearance of submerged vegetation in the 1990s resulted from degradation of the lake from the discharge of untreated sewage (Szyper et al. 1994). However, the dominant communities did not change. For years they have been Phragmitetum communis, Typhetum angustifoliae, and Nupharo-Nymphaeetum albae. Nymphaeides occurred abundantly near the tributary of the Cybina River and in the shallow, southwestern part of the lake throughout the analyzed period (Jenek et al. 1979, Kamiński 2000, Kowalczewska-Madura 2005). Notably, both species characteristic of Nupharo-Nymphaeetum albae (N. lutea and Nymphaea alba L.) occurred in Lake Swarzędzkie. They are partially protected under to Polish law.

Table 3

Changes in the distribution of macrophyte communities in Lake Swarzędzkie in the 1979-2012 period (before 1979 - Jenek et al. 1979; 1992 - Szyper et al. 1994; 2000-2002 - Kowalczewska-Madura 2005; 2005 - Gołdyn et al. 2005, 2006, 2007; 2008 WIOS 2008; 2012 - own study)

\begin{tabular}{|c|c|c|c|c|c|c|}
\hline \multirow[b]{3}{*}{ Community } & \multicolumn{6}{|c|}{ Years of research } \\
\hline & \multicolumn{5}{|c|}{ Before restoration } & \multirow{2}{*}{$\begin{array}{l}\text { During restoration } \\
2012\end{array}$} \\
\hline & Before 1979 & 1992 & $2000-2002$ & 2005 & 2008 & \\
\hline Phragmitetum communis Schmale 1939 & + & + & + & + & + & + \\
\hline Typhetum angustifoliae Soó 1927 & + & + & + & + & + & + \\
\hline Nupharo-Nymphaeetum albae Tomaszewicz 1977 & + & + & + & + & + & + \\
\hline Acoretum calami Kobendza 1948 & - & + & + & + & - & + \\
\hline Ceratophylletum demersi Hild 1956 & + & - & - & + & + & + \\
\hline Glycerietum maximae (Allorge 1922) Hueck 1931 & + & + & + & + & - & - \\
\hline Cicuto-Caricetum pseudocyperi de Boer 1942 & - & - & + & + & + & + \\
\hline Thelypteridi-Phragmitetum Kuiper 1957 & - & - & + & + & + & + \\
\hline Hydrocharitetum morsus-ranae Langendonck 1935 & - & - & - & + & + & + \\
\hline Caricetum acutiformis Eggler 1933 & - & + & + & - & + & - \\
\hline Iridetum pseudacori Eggler 1933 & - & + & + & - & + & - \\
\hline Ceratophylletum submersi Soó 1928 & - & - & - & + & + & - \\
\hline Potametum lucentis Hueck 1931 & + & - & - & - & - & + \\
\hline Ranunculetum circinati (Sauer 1937) Segal 1965 & + & - & - & - & - & - \\
\hline Potametum perfoliati (W.Koch 1926) Pass. 1964 & + & - & - & - & - & - \\
\hline Myriophylletum spicati Soó 1927 & + & - & - & - & - & - \\
\hline Potametum crispi Soó 1927 & + & - & - & - & - & - \\
\hline Scirpetum lacustris (Allorge 1922) Chouard 1924 & + & - & - & - & - & - \\
\hline Equisetetum fluviatilis Steffen 1931 & + & - & - & - & - & - \\
\hline Potametum pectinati (Hueck 1931) Carstensen 1955 & - & - & - & + & - & - \\
\hline Lemno-Spirodeletum polyrrhizae W. Koch 1954 & - & - & - & + & - & - \\
\hline $\begin{array}{l}\text { Caricetum paniculatae Wangerin } 1916 \text { ex von } \\
\text { Rochow } 1951\end{array}$ & - & - & - & - & + & - \\
\hline Caricetum ripariae Soó 1928 & - & & & - & + & - \\
\hline Typhetum latifoliae Soó 1927 & - & - & - & - & + & - \\
\hline The number of communities & 12 & 7 & 9 & 12 & 13 & 9 \\
\hline
\end{tabular}


Elodeides disappeared in the 1990s. They returned mostly in the southwestern shallow part of the lake at the beginning of the twenty-first century (Gołdyn et al. 2005). The association of hornwort (Ceratophylletum demersi) occurred first, and it is an indicator of highly eutrophic lakes (Kolada 2010). Submerged macrophytes appeared after appropriate catchment management was implemented mainly through the diversion of sewage after 1991 and the elimination of illegal waste water discharge (Kowalczewska-Madura and Gołdyn 2006). Restoration affected the spread of hydromacrophytes, mainly patches dominated by $C$. demersum. Numerous stands of Ceratophylletum demersi could indicate the positive impact of restoration measures, because as transparency increased light reached deeper into the water column, which was down to the bottom in the shallows of $1.5 \mathrm{~m}$. Favorable light conditions and the availability of nutrients create optimum conditions for the growth of hornwort. Undoubtedly, the high density of vegetation in the shallow part of the lake has a positive impact on the water quality because they comprise a filter that can retain and limit the growth of phytoplankton (Dai et al. 2012). Additionally, macrophytes take in and accumulate nutrients in their tissues. This contributes to reduced nutrient concentrations in the water. They are provide habitats for numerous invertebrate fauna (Dondajewska et al. 2007, Pieczyńska 2008).

Potamogeton lucens L. is a species that is characteristic of the Potametum lucentis community that appeared during the first year of restoration. It has not been observed for at least 20 years. Characteristically, this species occurs in remediation reservoirs (Immersa et al. 2014), and it is sensitive to trophic state (Kolada 2010). Hence, its presence indicates improved water quality. This community was observed only at one station with a surface area of about $40 \mathrm{~m}^{2}$. It is important to draw attention to its occurrence in the future, particularly as it is considered to be threatened in category I in the Wielkopolska Region (Brzeg and Wojterska 2001).

The pleustophytes Lemno-Spirodeletum polyrrhizae and Hydrocharitetum morsus-ranae (Gołdyn et al. 2005), together with communities such as Cicuto-Caricetum pseudocyperi and Thelypteridi-Phragmitetum (Kowalczewska-Madura 2005), have been observed for approximately ten years. This vegetation is typical of highly eutrophic waters that are supplied with nutrients mainly from the water column (Podbielkowski and Tomaszewicz 1996). The first of these associations disappeared relatively quickly (Table 3), and the range of the second is gradually decreasing. This means that the trophic status of the water has decreased. The patches of Caricetum acutiformis, Glycerietum maximae, and Iridetum pseudacori, which are communities that are characteristic of high trophic status, were not observed in 2012. However, shoreline vegetation could have been overlooked during field research because we focused mostly on aquatic vegetation. Communities that have been reported once should be observed to determine whether they occur again when water quality improves. Macrophyte observations and monitoring should be continued to assess the sustainability of treatments and the changes that occur. Many species of submerged macrophytes, including Potamogeton crispus L., Potamogeton perfoliatus L., Myriophyllum spicatum L., and Ranunculus circinatus Sibth. were observed in Lake Swarzędzkie during the 1970s (Jenek et al. 1979). They are expected to return in the future. The number of communities recorded in previous years was variable and ranged from 7 to 13 , which indicates that macrophytes react to changes in water quality. This also means that the ecosystem is unstable. According to Grzybowski et al. (2008), the average number of plant communities depends on lake type and ranges from 21 to 23 . The smaller number of associations in Lake Swarzędzkie indicates the low vegetal diversity of the phytolittoral. However, the number of communities (as long ago as 1979 there were only 12) is not as important as the changes taking place in the composition of vegetation, especially in the submerged communities.

Appropriate development of macrophytes, especially submerged ones, promotes the diversity and abundance of fish. The lake was classified to the bream-perch-pike type (Jenek et al. 1979). The extensive littoral zone and high biodiversity had created 
favorable conditions for fish spawning and juvenile development (Jenek et al. 1979). Roach, Rutilus rutilus (L.), bream, Abramis brama (L.), eel Anguilla anguilla (L.), pike E. lucius, pikeperch, Sander lucioperca (L.), and carp - Cyprinus carpio (L.) all occurred. The Fisheries Enterprise of the State Treasury in Bogucin reports that in the 1990s the lake was stocked with bighead carp, Hypophthalmichthys nobilis (Richardson) and silver carp, Hypophthalmichthys molitrix (Valenciennes), as well as eel montee, Anguilla anguilla (L.), bream, silver bream, Blicca bjoerkna (L.), and roach. Bighead carp and silver carp dominated the catches.

The average yield per hectare of $47.8 \mathrm{~kg} \mathrm{r}^{-1}$ clearly exceeded the average for Poland (Kowalczewska-Madura 2005). Roach, bream, and silver bream dominated catches performed with biomanipulation in fall 2011. Silver carp and bighead carp were not observed. The disappearance of these alien species could also play a role in the slow return of aquatic vegetation to Lake Swarzędzkie, as was the case in Lake Warniak (Hutorowicz and Dziedzic 2008). After the catches, the lake was stocked with pike fry (Kozak et al. 2014), to intensify trophic top-down pressure. The proper development of submerged vegetation is required to achieve effective biomanipulation (Hilt et al. 2006).

The return of aquatic vegetation is essential if positive restoration results are to be achieved (van Donk and Otte 1996). We have to be patient while observing the return, spread, and increasingly diverse plant species during restoration. The process extends over time, and it is always slower than the reactions of the other components of the ecosystem (Hilt et al. 2010).

Statistically significant changes in the concentration of chlorophyll-a and total nitrogen confirm improved water quality resulting from restoration treatments. Furthermore, total suspended solids and water transparency were markedly improved, although the differences were not yet statistically significant. The biodiversity of macrophytes decreased with increasing nitrogen concentrations (Qin et al. 2013, Moss et al. 2013), so it is important to observe this parameter carefully. It should therefore be assumed that the reduction of nitrogen concentrations will have a positive impact on the growth of hydrophyte diversity. These water quality indicators respond quickly to restoration treatments, but changes might not be permanent. Only changes in vegetation, especially submerged varieties, are evidence of persistent changes in ecosystems (Novak and Chambers 2014).

\section{Conclusions}

This study of the distribution and composition of aquatic vegetation suggests that the first significant changes occurred approximately ten years after protective measures were implemented (sewage diversion). Nevertheless, beginning restoration in Lake Swarzędzkie has intensified the changes. Improved water quality was indicated by significant reductions in chlorophyll-a and nitrogen concentrations as well as the gradual increase of water transparency and the decrease of total suspended solids. The northern, deeper part of the lake was characterized by extensive communities of Phragmitetum communis and Typhetum angustifoliae. In contrast, there were numerous patches of Nupharo-Nuphareteeum albae, Ceratophylletum demersi, as well as Cicuto-Caricetum pseudocyperi and Thelypteridi-Phragmitetum in the southwest, shallower part. In the northern part a patch of Potametum lucentis was noted, which is evidence of the water's trophic status decreasing. The high abundance of nymphaeides and elodeides has a positive influence on the biological method of restoration through biomanipulation. They provide suitable conditions for the development of predatory fish, especially pike, E. lucius. Continued research on composition variability and the area occupied by macrophytes in this lake is necessary as it will foster a better understanding of the complex processes occurring in this water ecosystem and provide information about the effectiveness of restoration measures. 
Acknowledgments. We would like to thank Kamila Stachura and Monika Konieczny for help with ArcGIS and Michał Rybak for help in the field.

Author contributions. J.R. participated in field research, analyzed macrophyte qualitative composition, elaborated data and wrote the manuscript; R.G. participated in field research and adjusted text of the manuscript.

\section{References}

Brzeg A., Wojterska M. 2001 - Greater Poland plant communities, the state of knowledge, and threats to them - In: Vegetation in Greater Poland and the Southern Pomeranian Lake District (Ed.) M. Wojterska, Guide to Field Sessions, 52. Zjazd PTB, September 24-28, 2001 Poznań: 39-110 (in Polish).

Celewicz-Gołdyn S., Joniak T., Kuczyńska-Kippen N., Messyasz B., Nagengast B., Stefaniak K. 2009 - In: Functioning of plankton assemblages in diversified habitats in small water basins in Greater Poland (Ed.) N. Kuczyńska-Kippen, Bonami Wydawnictwo Drukarnia, Poznań, 501 p. (in Polish).

Celewicz-Gołdyn S. 2010 - Influence of Ceratophyllum demersum L. on phytoplankton structure in a shallow eutrophic lake - Oceanol. Hydrobiol. Stud. 39: 121-128.

Ciecierska H., Kolada A. 2014 - ESMI: a macrophyte index for assessing the ecological status of lakes - Environ. Monit. Assess. 186: 5501-5517.

Ciurli A., Zuccarini P., Alpi A. 2009 - Growth and nutrient absorption of two submerged aquatic macrophytes in mesocosms, for reinsertion in a eutrophicated shallow lake - Wetlands Ecol. Manag. 17: 107-115.

Dai Y., Jia C., Liang W., Hu S., Wu Z. 2012 - Effects of the submerged macrophyte Ceratophyllum demersum L. on restoration of a eutrophic waterbody and its optimal coverage - Ecol. Eng. 40: 113-116.

Dondajewska R., Gołdyn R., Frankowski T. 2007 - Interactions between submerged macrophytes, macrophyte-associated macroinvertebrates and water quality parameters in shallow preliminary reservoir Teka Kom. Kszt. Ochr. Środ. Przyr. 4: 7-13.

Elbanowska H., Zerbe J., Siepak J. 1999 - Physicochemical Water Testing - Wyd. Uczelniane UAM. Poznań. 231 p. (in Polish).

Gołdyn R., Gołdyn H., Kaniewski W. 2005 - Water plant associations in the valley of the Cybina River - Rocz. AR Pozn., 373, Bot-Stec. 9: 69-87.

Gołdyn R., Gołdyn H., Kaniewski W. 2006 - Rush communities in the Cybina Valley (central Greater Poland). Part I:
Phragmition communis - Bad. Fizjogr. Pol. Zach., Seria B, Botanika 55: 79-89 (in Polish).

Gołdyn R., Gołdyn H., Kaniewski W. 2007 - Rush communities in the Cybina Valley (central Greater Poland). Part II: Magnocaricion elatae, Oenanthion aquaticae and Phalaridion - Bad. Fizjogr. Pol. Zach., Seria B, Botanika 56: 91-110 (in Polish).

Gołdyn R., Dondajewska R., Kowalczewska-Madura K., Rosińska J., Romanowicz-Brzozowska W. 2012 Changes in Lake Swarzędzkie water quality as a consequence of restoration measures. Poznań. http://www.swarzedz.pl/fileadmin/Pliki_info/

Pliki_info_2013/jezioro_-_sprawozdanie_roczne.pdf (in Polish).

Gołdyn R., Podsiadłowski S., Dondajewska R., Kozak A. 2014 - The sustainable restoration of lakes - towards the challenges of the Water Framework Directive - Ecohydrol. Hydrobiol. 14: 68-74.

Grzybowski M., Endler Z., Jaworska B. 2008 - Ecological status and macrophyte phytocenosis diversity in Lake Pasłęk in the Olsztyn Lake District - Zesz. Probl. Post. Nauk Rol. 532: 91-99 (in Polish).

Hao B., Wu H., Shi Q., Liu G., Xing W. 2013 - Facilitation and competition among foundation species of submerged macrophytes threatened by severe eutrophication and implications for restoration - Ecol. Eng. 60: 76-80.

Hilt S., Gross E.M., Hupfer M., Morscheid H., Mählmann J., Melzer A., Poltz J., Sandrock S., Scharf E-M., Schneider S., van de Weyer K. 2006 - Restoration of submerged vegetation in shallow eutrophic lakes - A guideline and state of the art in Germany - Limnologica 36: 155-171.

Hilt S., van de Weyer K., Köhler A., Chorus I. 2010 - Submerged macrophyte responses to reduced phosphorus concentrations in two Peri-Urban Lakes - Restor. Ecol. 18(S2): 452-461.

Hutorowicz A., Dziedzic J. 2008 - Long-term changes in macrophyte vegetation after reduction of fish stock in a shallow lake - Aquat. Bot. 88: 265-272.

Immers A.K., Vendrig K., Ibelings B.W., van Donk E., Ter Heerdt G.N.J., Geurts J.J.M., Bakker E.S. 2014 - Iron addition as a measure to restore water quality: Implications for macrophyte growth - Aquat. Bot. 116: 44-52.

Jańczak J. 1996 - Atlas of Polish Lakes. Vol I. The Lakes of the Greater Poland and Pomeranian Lake Districts within the Oder River Drainage Basin - IMGW, Poznań. Bogucki Wyd. Naukowe (in Polish).

Jenek B., Suszczewicz R., Deplewski A. 1979 - Description of fisheries districts in open waters in Poznań Voivodeship, part II - Poznań: 272-276 (in Polish).

Kamiński G. 2000 - Spatial pollution of lakes in the Cybina River catchment- Master's thesis, Department of Water Conservation, Uniwersytet im. Adama Mickiewicza (in Polish). 
Kłosowski S., Jabłońska E., Szańkowski M. 2011 - Aquatic vegetation as an indicator of littoral habitats and various stages of lake aging in north-eastern Poland - Ann. Limnol. 47: 281-295.

Kolada A. 2010 - The use of aquatic vegetation in lake assessment: testing the sensitivity of macrophyte metrics to anthropogenic pressures and water quality Hydrobiologia 656: 133-147.

Kolada A. 2014 - The effect of lake morphology on aquatic vegetation development and changes under the influence of eutrophication - Ecol. Indic. 38: 282-293.

Kolada A., Ciecierska H. 2008 - Field methodology for lake macrophyte study and biological monitoring of waters in accordance with the Water Framework Directive - Environmental and Natural Resources Conservation 37: 9-23 (in Polish).

Kowalczewska-Madura K. 2005 - Impact of changes in nutrient loads on the structure and functioning of the Lake Swarzędzkie ecosystem - Ph.D. thesis, Uniwersytet im. Adama Mickiewicza, Poznań (in Polish).

Kowalczewska-Madura K., Gołdyn R. 2006 - Anthropogenic changes in water quality in the Swarzędzkie Lake (West Poland) - Limnol. Rev. 6: 147-154.

Kozak A., Kowalczewska-Madura K., Gołdyn R., Czart A. 2014 - Phytoplankton composition and physicochemical properties in Lake Swarzędzkie (midwestern Poland) during restoration: Preliminary result - Arch. Pol. Fish. 22: 17-28.

Kuczyńska-Kippen N. 2009 - Functioning of plankton assemblages in the varied habitats of small water basins in Greater Poland - Bonami Wydawnictwo Drukarnia, Poznań (in Polish).

Kuczyńska-Kippen N., Nagengast B., Celewicz-Gołdyn S., Klimko M. 2009 - Zooplankton community structure within various macrophyte stands of a small water body in relation to seasonal changes in water level - Oceanol. Hydrobiol. Stud. 3: 125-133.

Liu G., Liu Z., Gu B., Smoak J. M., Zhang Z. 2014 - How important are trophic state, macrophyte and fish population effects on cladoceran community? A study in Lake Erhai - Hydrobiologia 736: 189-204.

Meijer M.-L. 2000 - Biomanipulation in the Netherlands. 15 years of experience - Ph.D. thesis, Wageningery University, Leystad, 206 p.

Melzer A. 1999 - Aquatic macrophytes as tools for lake management - Hydrobiologia 395/396: 181-190.

Moss B., Jeppesen E., Søndergaard M., Lauridsen T.L., Liu Z. 2013 - Nitrogen, macrophytes, shallow lakes and nutrient limitation: resolution of a current controversy? Hydrobiologia 710: 3-21.

Mulderij G., van Nesc E.H., van Donk E. 2007 - Macrophyte phytoplankton interactions: The relative importance of allelopathy versus other factors - Ecol. Model. 204: 85-92.
Nagengast B. 1994 - Macrophytes as a crucial element in lake diagnostics - In: Theory and practice in ecological studies (Ed.) L. Burchardt, Idee Ecol. 4, Ser. Szkice 3: 105-110 (in Polish).

Novak P.A., Chambers J.M. 2014 - Investigation of nutrient thresholds to guide restoration and management of two impounded rivers in south-western Australia - Ecol. Eng. 68: 116-123.

Oleksowicz A. 1988 - Algal community dynamics in Kashubian Lakes of various trophic status - Rozprawy UMK, 84 p. (in Polish).

Ozimek T., Gulati R.D., van Donk E. 1990 - Can macrophytes be useful in biomanipulation of lakes? The Lake Zwemlust example - Hydrobiologia 200/201: 399-407.

Pieczyńska E. 1993 - The littoral zone and lake eutrophication, conservation, and restoration - Wiad. Ekol. 39: 139-162 (in Polish).

Pieczyńska E. 2008 - Eutrophication in shallow lakes: Macrophyte significance - Wiad. Ekol. 54: 3-28 (in Polish).

Podbielkowski Z., Tomaszewicz H. 1996 - A Guide to Hydrobotony-Wyd. PWN, Warszawa, 530 p. (in Polish).

Qin B.Q., Gao G,. Zhu G. W., Zhang Y.L., Song Y.Z., Tang X.M., Xu H., Deng J.M. 2013 - Lake eutrophication and its ecosystem response - Chin. Sci. Bull. 58: 961-970.

Rosińska J., Gołdyn R., Podsiadłowski S., Dondajewska R., Kowalczewska-Madura K., Kozak A., Ruszkowska-Cichocka B. 2013 - Preliminary results of Lake Swarzędzkie restoration - In: Lake Conservation and Restoration (Ed.) R. Wiśniewski, Toruń: 189-198 (in Polish).

Scheffer M., Hosper S.H., Meijer M.-L., Moss B., Jeppesen E. 1993 - Alternative equilibria in shallow lakes - Trends Ecol. Evol. 8: 275-279.

Schriver P., Bøgestrand J., Jeppesen E., Søndergaard M. 1995 - Impact of submerged macrophytes on fish-zooplankton-phytoplankton interactions: large-scale enclosure experiments in a shallow eutrophic lake Freshwat. Biol. 33: 255-270.

Søndergaard M., Johansson L.S., Lauridsen T.L., Jørgensen T.B., Liboriussen L., Jeppesen E. 2010 - Submerged macrophytes as indicators of the ecological quality of lakes - Freshwat. Biol. 55: 893-908.

Srivastava J., Gupta A., Chandra H. 2008 - Managing water quality with aquatic macrophytes - Rev. Environ. Sci. Biotechnol. 7: 255-266.

Szyper H., Gołdyn R., Romanowicz W. 1994 - Lake Swarzędzkie and its influence upon the water quality of the River Cybina - In: Protection of the water of the catchment area of the River Cybina (Ed.) R. Gołdyn, Pr. Komis. Biol. PTPN, 74: 7-31.

van Donk E., Otte A. 1996 - Effects of grazing by fish and waterfowl on the biomass and species composition of submerged macrophytes - Hydrobiologia 340: 285-290. 
van Donk E., van de Bund W.J. 2002 - Impact of submerged macrophytes including charophytes on phyto- and zooplankton communities: allelopathy versus other mechanisms - Aquat. Bot. 72: 261-274.

Wang G.X., Zhang L.M., Chua H., Li X.D., Xia M.F., Pu P.M. 2009 - A mosaic community of macrophytes for the ecological remediation of eutrophic shallow lakes - Ecol. Eng. 35: 582-590.

WIOŚ 2008 - Report http://poznan.wios.gov.pl/gis/ ocena2008/jeziora_ocena / Ocena_jez_IOS_2008.pdf (in Polish). 